\title{
Sibjotang Increases Atrial Natriuretic Peptide Secretion in Beating Rabbit Atria
}

\author{
Oh Jeong Kwon, ${ }^{1,2}$ Hyun Cheol Oh, ${ }^{2,3}$ Yun Jung Lee, ${ }^{1,2}$ Hye Yoom Kim,, Rui Tan, ${ }^{1,2,4}$ \\ Dae Gill Kang, ${ }^{1,2,4}$ and Ho Sub Lee ${ }^{1,2,4}$ \\ ${ }^{1}$ College of Oriental Medicine and Professional Graduate School of Oriental Medicine, Wonkwang University, \\ Shinyong-dong, Iksan, Jeonbuk 570-749, Republic of Korea \\ ${ }^{2}$ Hanbang Body-Fluid Research Center, Wonkwang University, Shinyong-dong, Iksan, Jeonbuk 570-749, Republic of Korea \\ ${ }^{3}$ College of Pharmacy, Wonkwang University, Iksan 570-749, Republic of Korea \\ ${ }^{4}$ Brain Korea (BK) 21 Plus Team, Professional Graduate School of Oriental Medicine, Wonkwang University, Iksan, \\ Jeonbuk 540-749, Republic of Korea \\ Correspondence should be addressed to Dae Gill Kang; dgkang@wku.ac.kr and Ho Sub Lee; host@wku.ac.kr
}

Received 19 June 2015; Accepted 13 September 2015

Academic Editor: I-Min Liu

Copyright (C) 2015 Oh Jeong Kwon et al. This is an open access article distributed under the Creative Commons Attribution License, which permits unrestricted use, distribution, and reproduction in any medium, provided the original work is properly cited.

Sibjotang (Shizaotang), traditional herbal medicine formula, which was first documented in the Shanghanlun, has long been prescribed for the treatment of impairment of the body fluid homeostasis. The purpose of the present study was to identify the effects of Sibjotang on the secretion of a cardiac hormone, atrial natriuretic peptide (ANP), one of the main hormones involved in the regulation of the body fluid and blood pressure homeostasis. Water extract of Sibjotang increased ANP secretion concomitantly with an increase in atrial dynamics in a concentration-dependent manner. Sibjotang-induced increase in ANP secretion and positive inotropic effect were attenuated by GO6976 and LY333531, selective inhibitors of conventional protein kinase C, but not Rottlerin, an inhibitor of novel $\mathrm{PKC}_{\delta}$. Similarly to the effect of Sibjotang, extracts of components of Sibjotang, Euphorbia kansui, and Daphne genkwa, but not Euphorbia pekinensis and Ziziphus jujuba, increased ANP secretion and atrial dynamics. Ingredients of Sibjotang, apigenin, rosmarinic acid, and salvianolic acid B decreased ANP secretion and atrial dynamics. These findings suggest that Sibjotang increases ANP secretion and atrial dynamics via activation of conventional protein kinase $\mathrm{C}$ signaling. This finding provides experimental evidence for the rationale in the use of Sibjotang in the treatment of impairment of the regulation of body fluid and blood pressure homeostasis.

\section{Introduction}

Regulation of body fluid homeostasis is considered to be important to maintain healthy body function. Both humoral and autonomic nervous systems are involved in the regulation of body fluid homeostasis. Cardiac atria are the site of sensing the change of fluid volume and responding to correct the change via the secretion of atrial natriuretic peptide (ANP, atrial natriuretic hormone), a member of the family of cardiac natriuretic hormones. ANP is synthesized and stored in and released from the cardiac myocytes. The natriuretic peptide receptors coupled with guanylyl cyclase or nonguanylyl cyclase signaling are widely distributed throughout the whole body including the cardiorenal system $[1,2]$. The natriuretic peptide system is classically involved in the regulation of body fluid volume and blood pressure homeostasis via cardiorenal communication. ANP increases urinary excretion of water and electrolytes and decreases blood pressure via activation of natriuretic peptide receptors coupled with guanylyl cyclasecGMP signaling. In addition to the classical effects, the ANP system is also involved in the antioxidative, anti-ischemic, anti-inflammatory, and antiproliferative functions [3-5]. Furthermore, the ANP system is involved in the regulation of energy homeostasis including lipid mobilization $[6,7]$. Plasma ANP levels are primarily controlled by the rate of secretion of ANP from the atria. ANP secretion from the atria is under the control of atrial volume changes, adrenergic and muscarinic influences, and hormones [8-10]. Intracellular 
second messengers including cGMP, cAMP, $\mathrm{Ca}^{2+}$, and $\mathrm{K}^{+}$ channels are involved in the regulation of ANP secretion $[9,11]$. Activation of protein kinase $\mathrm{C}(\mathrm{PKC})$ is also known to increase ANP secretion [12].

Sibjotang (Jyusoto in Japanese, Shizaotang in Chinese), traditional herbal medicine formula, has been prescribed for the treatment of impairment of the regulation of body fluid homeostasis such as edema in Asian countries. The formula is composed of four component herbal medicines: Euphorbia kansui, Euphorbia pekinensis, Daphne genkwa, and Ziziphus jujube. Sibjotang was first written in Shanghanlun, an old medical book of China. Although the formula has long been prescribed, the mechanism of action of the formula has not yet been identified. The purpose of the present study was to identify the acute and direct effects of water extract of Sibjotang (SJ) on the secretory and contractile function of the cardiac atria and the regulation of ANP secretion in perfused beating rabbit atria.

\section{Methods and Materials}

2.1. Reagents. GO6976(GO), LY333531 (LY), Rottlerin (Rott), rosmarinic acid, and apigenin were purchased from Sigma Chemical Co. (Yongin, Korea). Salvianolic acid B was purchased from Santa Cruz (Santa Cruz, CA, USA). Stock solutions of GO, LY, Rott, and apigenin were dissolved in dimethyl sulfoxide (DMSO). Salvianolic acid B and rosmarinic acid were dissolved in distilled water. The final concentration of DMSO was less than $0.1 \%$.

2.2. Preparation of a Water Extract from Sibjotang (SJ). Sibjotang is composed of four medicinal herbs, Euphorbia kansui (37.5 g), Euphorbia pekinensis (37.5 g), Daphne genkwa (37.5 g), and Ziziphus jujube (85g). The above medicinal herbs were purchased from the Herbal Medicine Cooperative Association of Iksan, Jeonbuk. Herbarium voucher specimens of SJ (HBG132) were prepared and deposited in the Herbarium of the Professional Graduate School of Oriental Medicine, Wonkwang University, Iksan, Korea. Euphorbia kansui, Euphorbia pekinensis, Daphne genkwa, and Ziziphus jujube were prepared and deposited in the same sites, too. Mixture of the dried herbs (197.5 g) was extracted with 2,000 mL of boiling distilled water for $2 \mathrm{~h}$. The extract was filtered through Whatman number 5 filter paper and concentrated using rotary evaporator. Freeze-dried extract (SJ, $44 \mathrm{~g}$ ) was obtained and stored at desiccated deep freezer until used. Extraction of component herbs of SJ was performed similarly.

2.3. Atrial Preparation. Male New Zealand White rabbits $(\sim 1.8 \mathrm{~kg})$ were used. The study was carried out with the approval of the Institutional Animal Care and Utilization Committee for Medical Science of Wonkwang University. Rabbits were anesthetized with Ketamine $(50 \mathrm{mg} / \mathrm{kg}$, iv). After anesthesia, rabbits were exsanguinated and the heart was dissected and remaining blood was washed in oxygencontaining saline solution. The left atrium was isolated. Preparation of perfused beating atria was followed by the method previously described [13]. A transparent cannula containing 2 smaller polyethylene tubings inside the cannula was introduced into the atrial lumen. Transparent cannula has the scale outside. A platinum wire was located inside the cannula allowing transmural electrical field stimulation. One polyethylene tubing within the cannula was used to infuse perfusion fluid (HEPES buffer, $1 \mathrm{~mL} / \mathrm{min}$ ) and the other one was used to measure the changes in pressure inside the atrium. A cannulated atrium immediately transferred to an organ chamber maintained at $34^{\circ} \mathrm{C}$ and stimulated by electrical stimulation $(1.3 \mathrm{~Hz}, 0.3-0.5 \mathrm{~ms}, 30-40 \mathrm{~V})$. The organ chamber contained $3 \mathrm{~mL}$ buffer solution which is the same composition as the perfusion fluid and the chamber was supplied with oxygen by silicone tubing inside. The composition of the HEPES buffer follows (mM): $118 \mathrm{NaCl}, 4.7$ $\mathrm{KCl}, 2.5 \mathrm{CaCl}_{2}, 1.2 \mathrm{MgCl}_{2}, 25 \mathrm{NaHCO}_{3}, 10$ glucose, 10 HEPES, and $0.1 \%$ bovine serum albumin $(\mathrm{pH} 7.4)$. Atrial pressure was measured continuously by PowerLab/8SP (model ML 785, AD Instruments, Australia). The atrial stroke volume was measured by measuring the change of the diastolic and systolic levels of the water column of the transparent cannula. Perfusate was collected at every $2 \mathrm{~min}$ in a test tube in ice-cold water bath.

2.4. Experimental Protocols. The beating atria were perfused with buffer solution for $40 \mathrm{~min}$ to stabilize pulse pressure, stroke volume, and ANP secretion. The perfusate was collected serially at $2 \mathrm{~min}$ intervals at $4^{\circ} \mathrm{C}$ for analysis. Experiments were carried out using 24 groups of atria (Figure 1) to answer the following questions.

2.4.1. Does SJ Affect Atrial ANP Release? To identify the effects of SJ, $12 \mathrm{~min}$ of control was followed by $72 \mathrm{~min}$ of SJ (group 1, $0 \mu \mathrm{g} / \mathrm{mL}, n=6$; group 2, $60 \mu \mathrm{g} / \mathrm{mL}, n=8$; group 3, $100 \mu \mathrm{g} / \mathrm{mL}, n=8$; group 4, $300 \mu \mathrm{g} / \mathrm{mL}, n=5$; and group 5, $1,000 \mu \mathrm{g} / \mathrm{mL}, n=5)$. To test the recovery from the effects of SJ, $36 \mathrm{~min}$ of SJ infusion was followed by $72 \mathrm{~min}$ of buffer only (group 6, 1,000 $\mu \mathrm{g} / \mathrm{mL}, n=4$ ).

2.4.2. Are the SJ-Induced Changes in ANP Release Related to PKC Pathway? In another series of experiments to identify the mechanisms involved, $12 \mathrm{~min}$ of control was followed by an inhibitor of $\mathrm{PKC}_{\alpha}, \mathrm{PKC}_{\beta}$, or $\mathrm{PKC}_{\delta}$ for $36 \mathrm{~min}$ and then $\mathrm{SJ}$ in the presence of previous agent for $72 \mathrm{~min}$ (group 7, DMSO $0.1 \%+$ SJ $100 \mu \mathrm{g} / \mathrm{mL}, n=9$; group 8, GO6976 (GO) $100 \mathrm{nM}$ + SJ $100 \mu \mathrm{g} / \mathrm{mL}, n=9$; group 9, LY333531 (LY) $30 \mathrm{nM}+\mathrm{SJ}$ $100 \mu \mathrm{g} / \mathrm{mL}, n=12$; group 10, LY $100 \mathrm{nM}+\mathrm{SJ} 100 \mu \mathrm{g} / \mathrm{mL}, n=$ 8; group 11, Rottlerin (Rott) $1,000 \mathrm{nM}+\mathrm{SJ} 100 \mu \mathrm{g} / \mathrm{mL}, n=8$; group 12, DMSO 0.1\% + vehicle, $n=8$; group 13, GO $100 \mathrm{nM}+$ vehicle, $n=5$; group 14, LY $30 \mathrm{nM}+$ vehicle, $n=6$; group 15 , LY $100 \mathrm{nM}+$ vehicle, $n=5$; and group 16 , Rott $1,000 \mathrm{nM}+$ vehicle, $n=6$ ).

\subsubsection{Do Components and Each Herb Affect Atrial ANP} Release? In another series of experiments, effects of extract of the component herbs of the formula, Euphorbia kansui, Euphorbia pekinensis, Daphne genkwa, and Ziziphus jujube, were tested separately (group 1, vehicle control, $n=6$; group 17, Euphorbia kansui $200 \mu \mathrm{g} / \mathrm{mL}, n=7$; group 18, Daphne genkwa $200 \mu \mathrm{g} / \mathrm{mL}, n=7$; group 19, Euphorbia pekinensis $200 \mu \mathrm{g} / \mathrm{mL}, n=7$; and group 20, Ziziphus jujube $400 \mu \mathrm{g} / \mathrm{mL}$, 


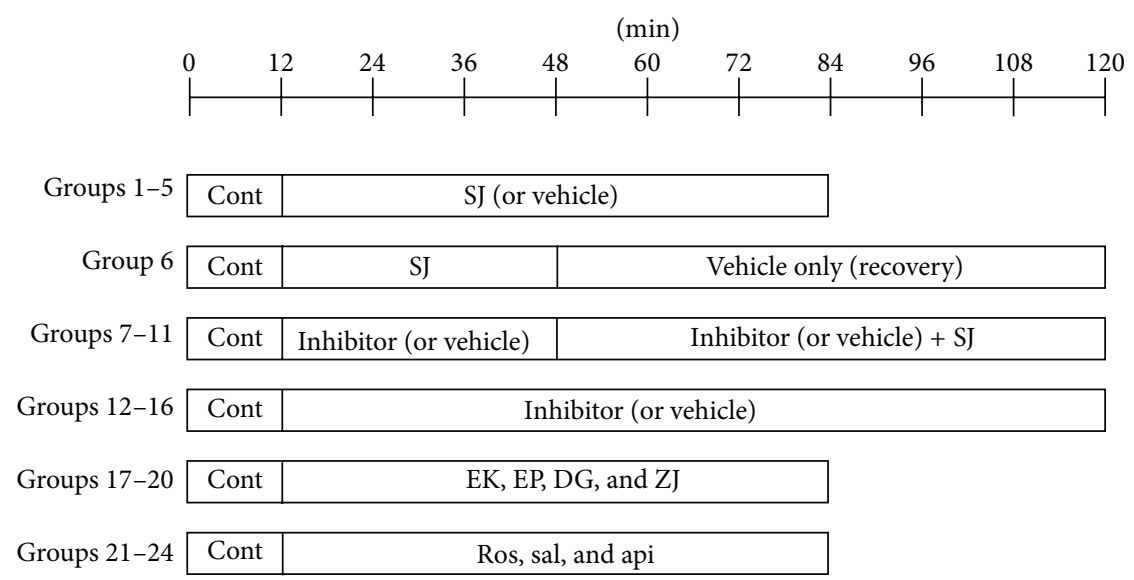

Figure 1: Protocols for present experiments. Atria were paced $1.3 \mathrm{~Hz}$. The values (means of two fractions) obtained before and after the addiction of vehicle (LY333531, GO6976, Rottlerin). Cont: control; SJ: Sibjotang; LY: LY333531; GO: GO697; Rott: Rottlerin; EK, Euphorbia kansui; EP: Euphorbia pekinensis; DG: Daphne genkwa; ZJ: Ziziphus jujube; ROS: rosmarinic acid; SAL: salvianolic acid B; API: apigenin. See Section 2.4 for details.

$n=7)$. In another series of experiments, effects of apigenin (api), rosmarinic acid (ros), and salvianolic acid B (sal) were tested (data not shown). Twelve min of control was followed by $72 \mathrm{~min}$ of water extract of component herbs or vehicle (group 1, control for rosmarinic acid and salvianolic acid B, $n=6$; group 21, control for apigenin, DMSO 0.1\%, $n=5$; group 22, apigenin $10 \mathrm{nM}, n=5$; group 23, rosmarinic acid, $1.0 \mu \mathrm{M}, n=5$; and group 24, salvianolic acid B, $1.0 \mu \mathrm{M}, n=5$ ).

2.5. Radioimmunoassay for ANP. The concentration of ANP in perfusate was measured by a specific radioimmunoassay published previously [8]. Measurement of ANP was carried out using Tris-acetate buffer $(0.1 \mathrm{M}, \mathrm{pH} 7.4 ; 0.2 \%$ neomycin, $1 \mathrm{mM}$ EDTA, 50 BAEE units/mL SBTI, $0.002 \%$ sodium azide, and $1 \%$ bovine serum albumin). Bound and free form was separated with a charcoal suspension. The secreted amount of ANP was expressed as nanograms ANP per minute per gram of atrial wet weight.

2.6. Assay for Lactic Dehydrogenase Activity. Lactic dehydrogenase (LDH) activity was measured using a commercially available assay kit (Asan Pharmaceutical, Seoul, Korea) according to the manufacturer's instruction. Absorbance was measured at $340 \mathrm{~nm}$ in a microplate reader (Infinite F200 Pro, Tecan).

2.7. HPLC Fingerprinting and NMR Spectroscopy. The chromatographic fingerprint of SJ was performed on a YOUNGLIN system (YOUNGLIN Instrument, Korea) equipped with YOUNGLIN UV detector (UV 730D) and ZAM 3000 Evaporative Light Scattering Detector (Schambeck SFD GmbH, Bad Honnef, Germany). Chromatographic separation was carried out on a YMC C ${ }_{18}$ column $(4.6 \mathrm{~mm} \times$ $150 \mathrm{~mm}, 5 \mu \mathrm{m})$ at room temperature with an injection volume of $30 \mu \mathrm{L}$ using a gradient elution of $10 \%$ methanol in water $(0.1 \%$ formic acid) to $25 \%$ methanol in over $10 \mathrm{~min}$ and then to $50 \%$ methanol in water over $40 \mathrm{~min}$, to $78 \%$ methanol in water over $25 \mathrm{~min}$, and to $100 \%$ methanol over $1 \mathrm{~min}$, followed by $100 \%$ methanol over $9 \mathrm{~min}$. Peaks were detected simultaneously both at $210 \mathrm{~nm}$ and $254 \mathrm{~nm}$ of UV detection. The presence and identification of compounds were confirmed by comparisons of retention times of respective isolated compounds in the above analytical HPLC conditions (Figure 2(b)).

A portion of SJ ( $4.5 \mathrm{~g}$ ) was then subjected to octadecyl functionalized silica gel flash column $(75 \mu \mathrm{m}$ particle size $5 \times 38 \mathrm{~cm})$ chromatography. The column was eluted with a stepwise gradient of $20 \%, 50 \%, 80 \%$, and $100 \% \mathrm{MeOH}$ in $\mathrm{H}_{2} \mathrm{O}$ (four subfractions, $500 \mathrm{~mL}$ each), affording Fr. 1 to Fr. 4. The fraction eluted at $50 \% \mathrm{MeOH}$ in $\mathrm{H}_{2} \mathrm{O}$ was then reapplied to octadecyl functionalized silica gel flash column $(75 \mu \mathrm{m}$ particle size $5 \times 20 \mathrm{~cm}$ ) chromatography, eluting with a stepwise gradient of $\mathrm{MeOH}$ in $\mathrm{H}_{2} \mathrm{O}$ (from $10 \%$ to $80 \%$ with $10 \%$ increment, 8 fractions, $300 \mathrm{~mL}$ each). A portion $(25.0 \mathrm{mg})$ of the fraction $(78.1 \mathrm{mg})$ that eluted with $30 \%$ $\mathrm{MeOH}$ in $\mathrm{H}_{2} \mathrm{O}$ was further purified by semipreparative reversed-phase HPLC (Shiseido MG prep- $\mathrm{C}_{18}$ column $(21.2 \times$ $150 \mathrm{~mm} ; 5 \mu \mathrm{m}$ particle size); $5 \mathrm{~mL} / \mathrm{min} ; 254 \mathrm{~nm}$ detection), eluting with a gradient from 10 to $100 \% \mathrm{MeOH}$ in $\mathrm{H}_{2} \mathrm{O}(0.1 \%$ formic acid) over $60 \mathrm{~min}$ to yield a mixture of compounds 1 and $2\left(t_{R}=35.8 \mathrm{~min}\right)$ and $3\left(3.1 \mathrm{mg}, t_{R}=38.2 \mathrm{~min}\right)$. A mixture of compounds 1 and $\mathbf{2}$ was further purified by additional semipreparative reversed-phase HPLC (Agilent prep- $\mathrm{C}_{18}$ column $(21.2 \times 150 \mathrm{~mm} ; 5 \mu \mathrm{m}$ particle size $) ; 5 \mathrm{~mL} / \mathrm{min} ; 254 \mathrm{~nm}$ detection), eluting with a gradient from 40 to $65 \% \mathrm{MeOH}$ in $\mathrm{H}_{2} \mathrm{O}$ (0.1\% formic acid) over $40 \mathrm{~min}$ to afford compounds 1 $\left(3.2 \mathrm{mg}, t_{R}=20.3 \mathrm{~min}\right)$ and $2\left(1.0 \mathrm{mg}, t_{R}=21.7 \mathrm{~min}\right) . \mathrm{A}$ portion $(36.5 \mathrm{mg})$ of the fraction $(55.3 \mathrm{mg})$ that eluted with $80 \% \mathrm{MeOH}$ in $\mathrm{H}_{2} \mathrm{O}$ from the first column chromatography was further purified by semipreparative reversed-phase HPLC (Shiseido MG prep-C ${ }_{18}$ column $(21.2 \times 150 \mathrm{~mm} ; 5 \mu \mathrm{m}$ particle size); $5 \mathrm{~mL} / \mathrm{min}$; $254 \mathrm{~nm}$ detection), eluting with a gradient from 40 to $75 \% \mathrm{MeOH}$ in $\mathrm{H}_{2} \mathrm{O}(0.1 \%$ formic acid) 
<smiles>O=C(/C=C/c1ccc(O)c2c1[C@@H](C(=O)O[C@H](Cc1ccc(O)c(O)c1)C(=O)O)[C@H](c1ccc(O)c(O)c1)O2)C[C@@H](Cc1ccc(O)c(O)c1)C(=O)O</smiles><smiles>[R6]c1cc(O)c2c(=O)cc(-c3ccc(O)cc3)oc2c1</smiles>

3: $\mathrm{R}=$ glucuronide 5: $\mathrm{R}=\mathrm{H}$<smiles>O=C(/C=C/c1ccc(O)c(O)c1)OC(Cc1ccc(O)c(O)c1)C(=O)O</smiles>

2

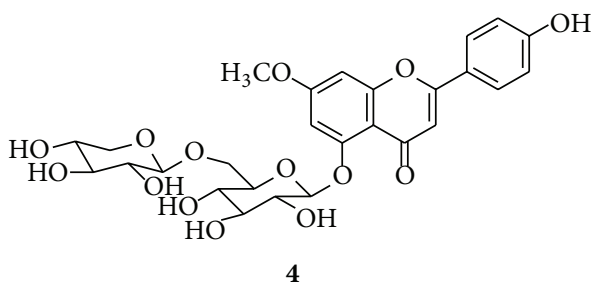

(a)

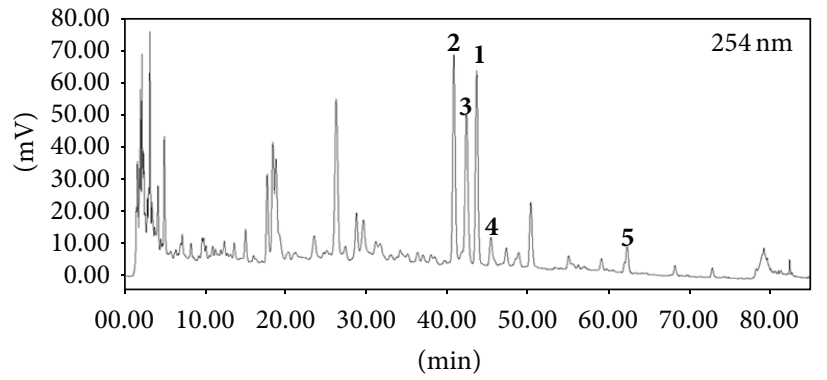

(b)

FIGURE 2: HPLC profile and H NMR analysis of Sibjotang. (a) Chemical structures of compounds. Number 1 is salvianolic acid B, number 2 is rosmarinic acid, number 3 is apigenin 7-O-b-glucuronide, number 4 is yuankanin, and number 5 is apigenin. It is analyzed by $1 \mathrm{D}-$ and 2D-NMR data; (b) HPLC chromatographic profile of the extract of SJ. Peak numbers correspond to structures given in (a), and the identity of the compounds was confirmed by retention times of isolated compounds.

over $40 \mathrm{~min}$ to yield compounds $4\left(3.1 \mathrm{mg}, t_{R}=21.5 \mathrm{~min}\right)$ and $5\left(2.8 \mathrm{mg}, t_{R}=37.6 \mathrm{~min}\right)$.

NMR spectra (1D and 2D) were recorded using a JEOL JNM ECP-400 spectrometer $\left(400 \mathrm{MHz}\right.$ for ${ }^{1} \mathrm{H}$ and $100 \mathrm{MHz}$ for ${ }^{13} \mathrm{C}$ ), and chemical shifts were referenced relative to the corresponding residual solvents signals. HSQC and HMBC experiments were optimized for ${ }^{1} J_{\mathrm{CH}}=140 \mathrm{~Hz}$ and ${ }^{n} J_{\mathrm{CH}}=$ $8 \mathrm{~Hz}$, respectively.

2.8. Statistical Analysis. The significance of the results was validated by one-way ANOVA with Bonferroni's multiplecomparison test and Student's $t$-test. $P<0.05$ was considered as significant difference.

\section{Results}

3.1. HPLC Profile and H NMR Analysis. The structures of the compounds 1-5 were identified as salvianolic acid B $[14,15]$, rosmarinic acid [16], apigenin 7-O-b-glucuronide, apigenin [17], and yuankanin [18], respectively, by analysis of 1D- and 2D-NMR data and comparisons with those reported
(Figures 2(a) and 2(b)). The contents of the compounds 15 in the extract were estimated as $0.2 \%(\mathrm{w} / \mathrm{w}), 0.06 \%(\mathrm{w} / \mathrm{w})$, $0.2 \%(\mathrm{w} / \mathrm{w}), 0.1 \%(\mathrm{w} / \mathrm{w})$, and $0.09 \%(\mathrm{w} / \mathrm{w})$, respectively, on the basis of the isolation yields for the respective compounds.

3.2. SJ Increases ANP Secretion in a Concentration-Dependent Manner. Basal levels of ANP secretion remain steady and stable during experimental period in perfused beating atria (Figure 3(a)(A)). Similarly, atrial dynamics, pulse pressure, and stroke volume were stable (Figures $3(\mathrm{a})(\mathrm{B})$ and $3(\mathrm{a})(\mathrm{C})$ ). Vehicle (vehicle for modulator, DMSO, $0.1 \%$ ) had no significant effects on the basal levels of ANP secretion and atrial dynamics. SJ $(100 \mu \mathrm{g} / \mathrm{mL})$ significantly increased ANP secretion, pulse pressure, and stroke volume (Figure 3(b)). SJ-induced increase in ANP secretion and positive inotropic effects were concentration-dependent (Figure 4). The increase in ANP secretion and atrial dynamics by $\mathrm{SJ}(1,000 \mu \mathrm{g} / \mathrm{mL})$ was persistent after replacing the buffer without the agent (Figure 5). The SJ-induced increase in ANP secretion was significantly higher than control up to 48 min after cessation of the drug (Figure 5(a)). Similarly, the 


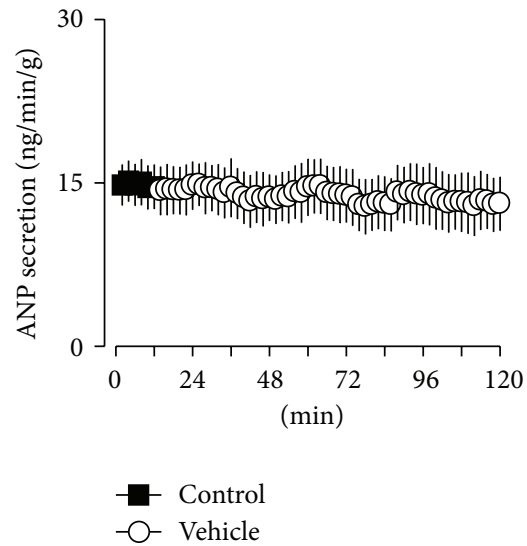

(A)

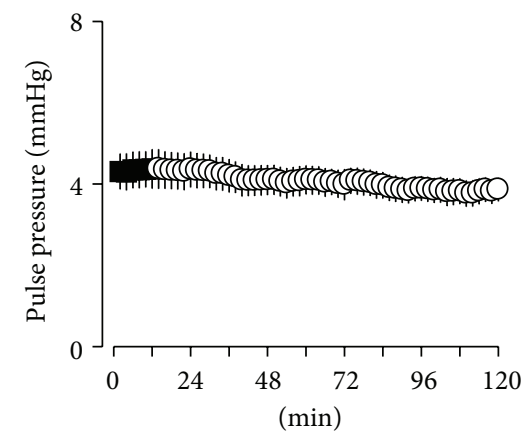

- Control

-O- Vehicle

(B)

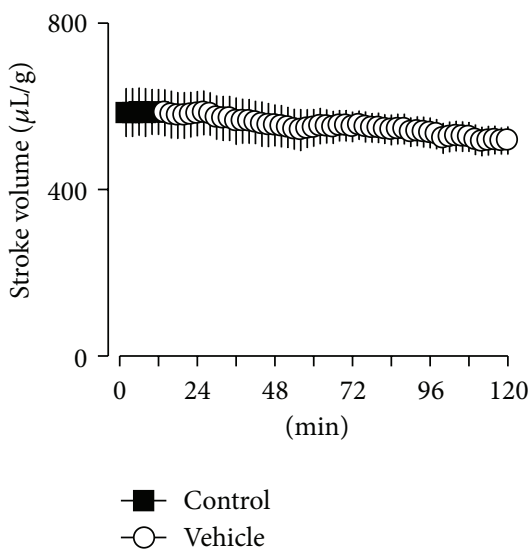

(C)

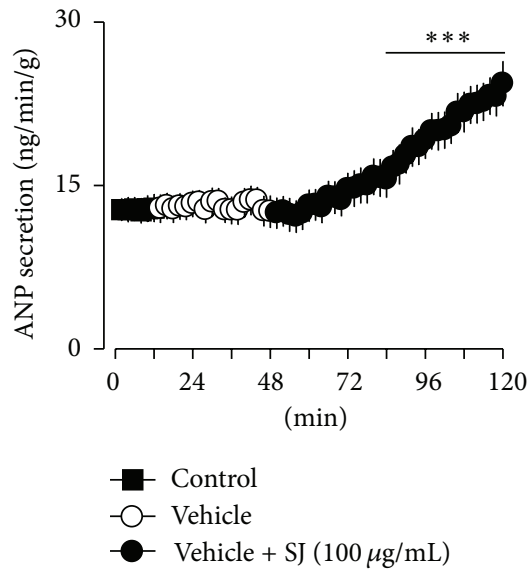

(A)

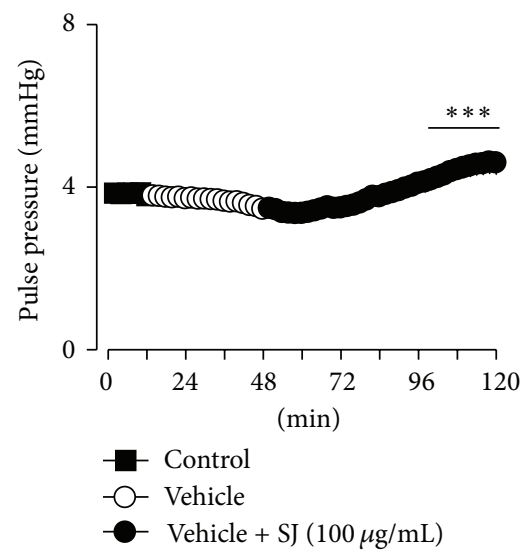

(B)

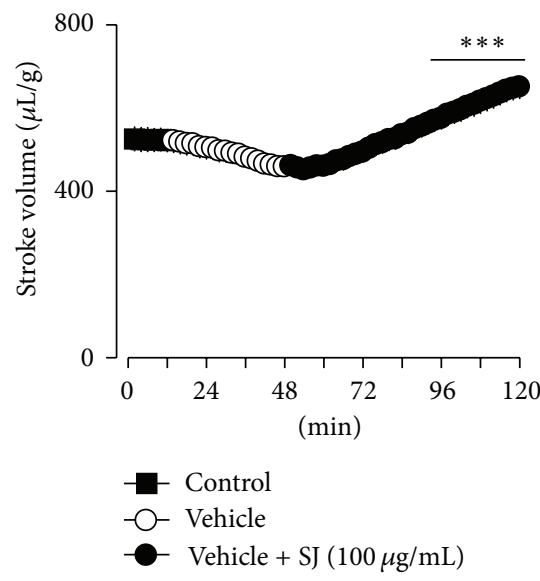

(C)

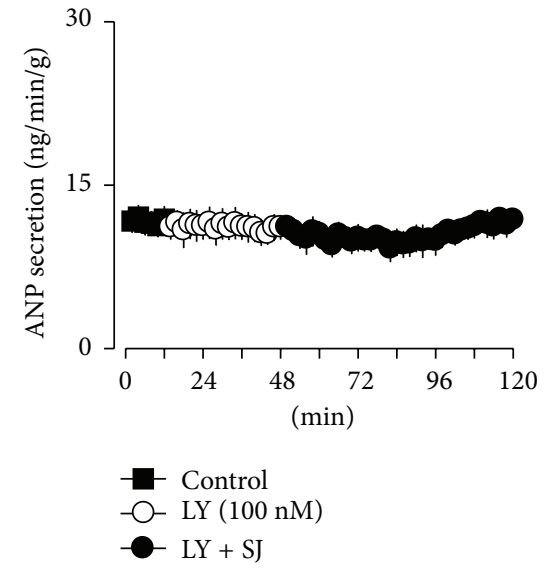

(A)

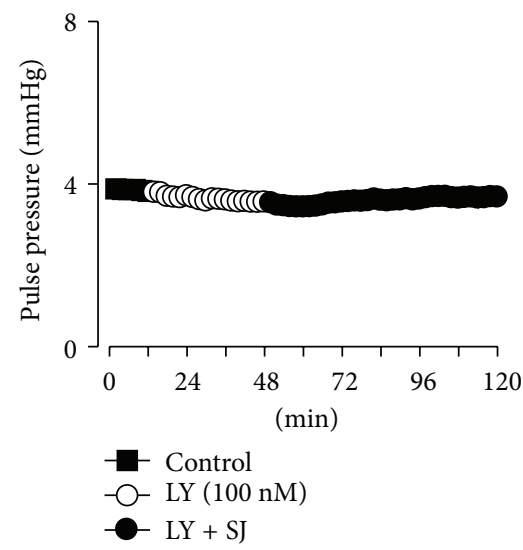

(B)

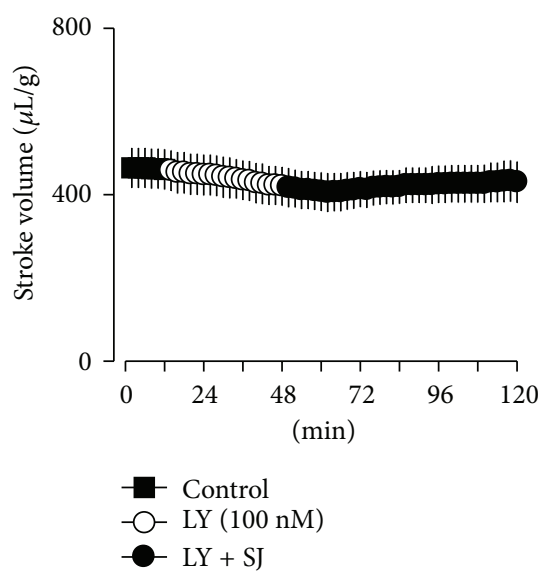

(C)

(a)

(b)

(c)

FIGURE 3: Effects of Sibjotang (SJ) on secretory and contractile function in perfused beating rabbit atria. (a) Effects of vehicle (DMSO 0.1\%) on ANP secretion (A), pulse pressure (B), and stroke volume (C). (b) Effects of SJ (100 $\mu \mathrm{g} / \mathrm{mL})$ on ANP secretion, pulse pressure, and stroke volume. (c) Effects of LY333531 (LY, $100 \mathrm{nM}$ ) on the SJ-induced increase in ANP secretion, pulse pressure, and stroke volume. Values are mean \pm SE. Number of experiments: control, $n=8$; SJ, $n=9$; and LY + SJ, $n=8 .{ }^{* * *} P<0.001$ versus mean values of two fractions before SJ. 


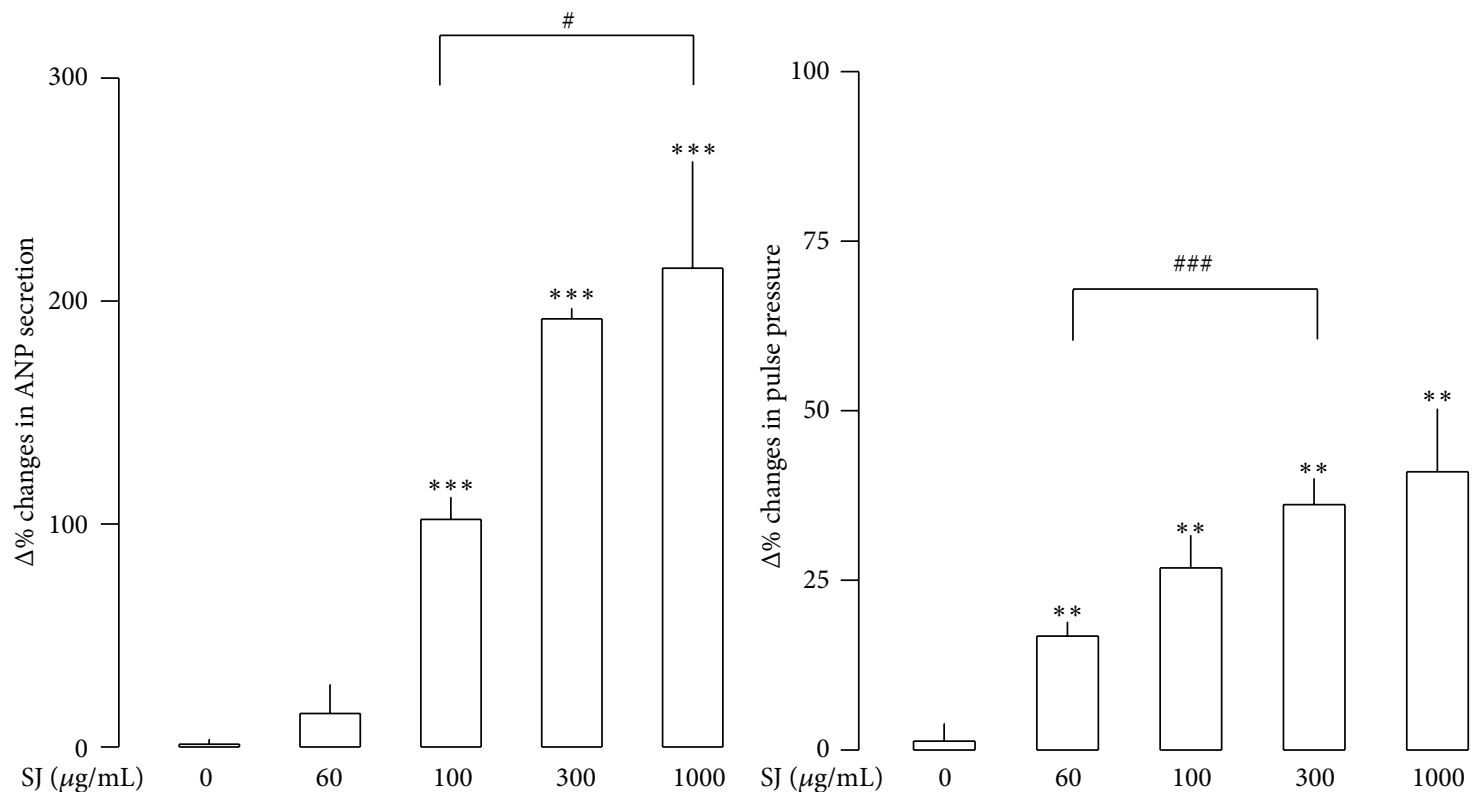

(a)

(b)

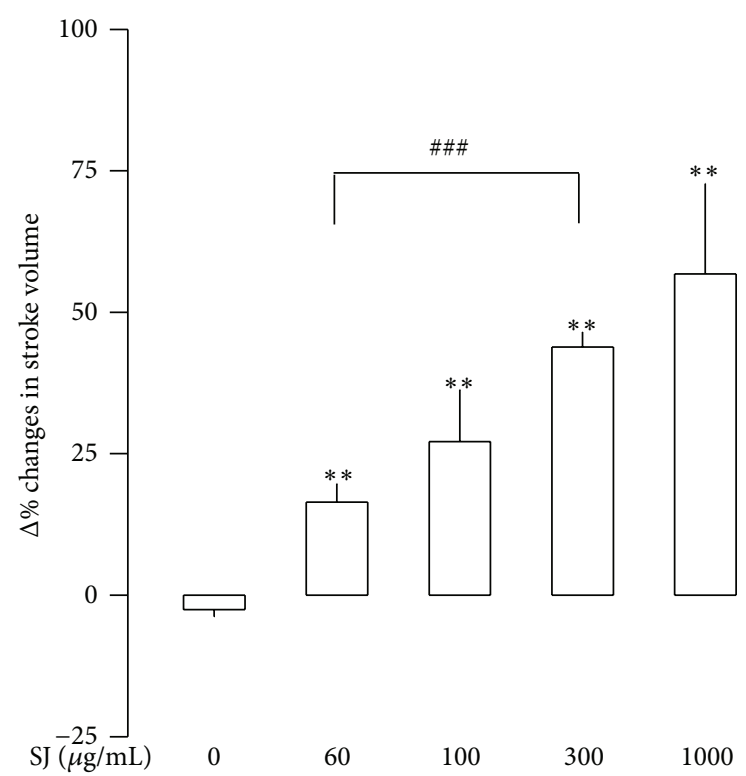

(c)

FIgURE 4: Concentration-dependent effects of Sibjotang (SJ) on ANP secretion, pulse pressure, and stroke volume in atria. (a) Effects of SJ on ANP secretion. (b) Effects of SJ on pulse pressure. (c) Effects of SJ on stroke volume. Values are mean \pm SE. Number of experiments: SJ $\left(0 \mu \mathrm{g} / \mathrm{mL}\right.$, control), $n=6$; SJ $(60 \mu \mathrm{g} / \mathrm{mL}), n=8$; SJ $(100 \mu \mathrm{g} / \mathrm{mL}), n=8$; SJ $(300 \mu \mathrm{g} / \mathrm{mL}), n=5$; and SJ $(1,000 \mu \mathrm{g} / \mathrm{mL}), n=5 .{ }^{* *} P<0.01$, ${ }^{* * *} P<0.001$ versus mean values of two fractions before SJ; ${ }^{\#} P<0.05,{ }^{\# \# \#} P<0.001$ versus control.

SJ- $(1,000 \mu \mathrm{g} / \mathrm{mL})$ induced positive inotropic effect remained elevated after the cessation of the drug (Figure 5(c)). In relation to the data of Figure 5, the levels of the LDH activity in perfusate showed no significant changes with SJ $(100 \mu \mathrm{g} / \mathrm{mL})$ (data not shown). Higher concentration of SJ $(1,000 \mu \mathrm{g} / \mathrm{mL})$ showed a transient but significant increase in the $\mathrm{LDH}$ activity in perfusate which was returned back to the control levels after cessation of the agent $(3.93 \pm 1.15 \%$ after $36 \mathrm{~min}$ of SJ, $P<0.05$ versus control period; $-1.06 \pm 1.45 \%$ after 24 min of cessation of SJ, $P>0.05$ versus control period).
These findings indicated that SJ increased ANP secretion and atrial dynamics in a concentration-dependent manner.

3.3. SJ Increases ANP Secretion and Atrial Dynamics via PKC Pathway. To identify the mechanisms involved in the SJ-induced changes in secretory and contractile function, effects of subtype-selective inhibitors of PKC were tested. LY, a selective inhibitor of $\mathrm{PKC}_{\beta}$, dose-dependently attenuated the SJ-induced increase in ANP secretion (Figures 3(c) and 6). LY (100 nM) completely inhibited SJ- $(100 \mu \mathrm{g} / \mathrm{mL})$ 


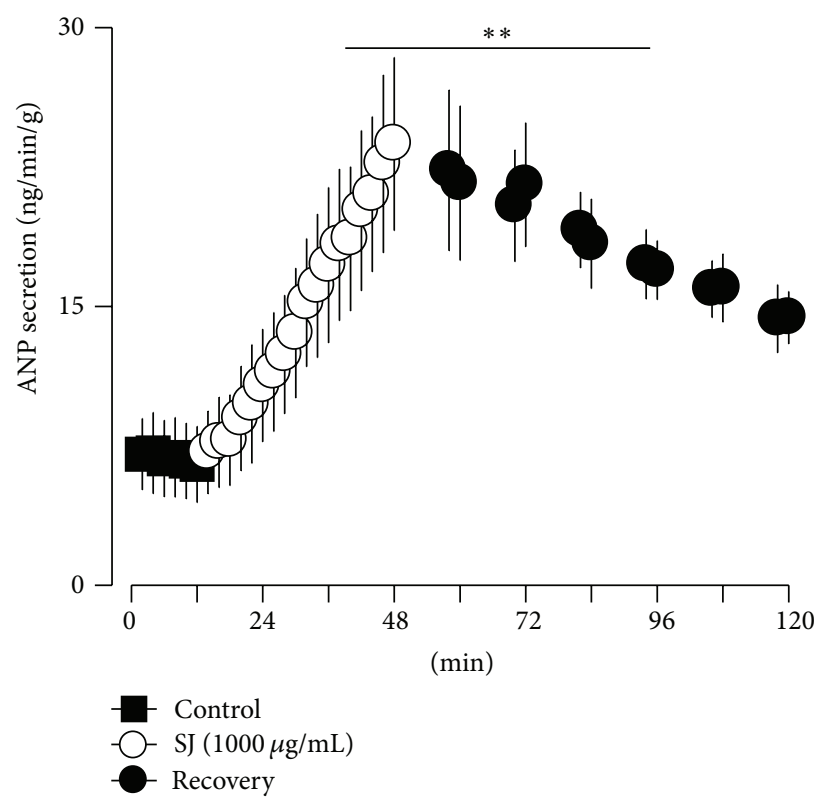

(a)

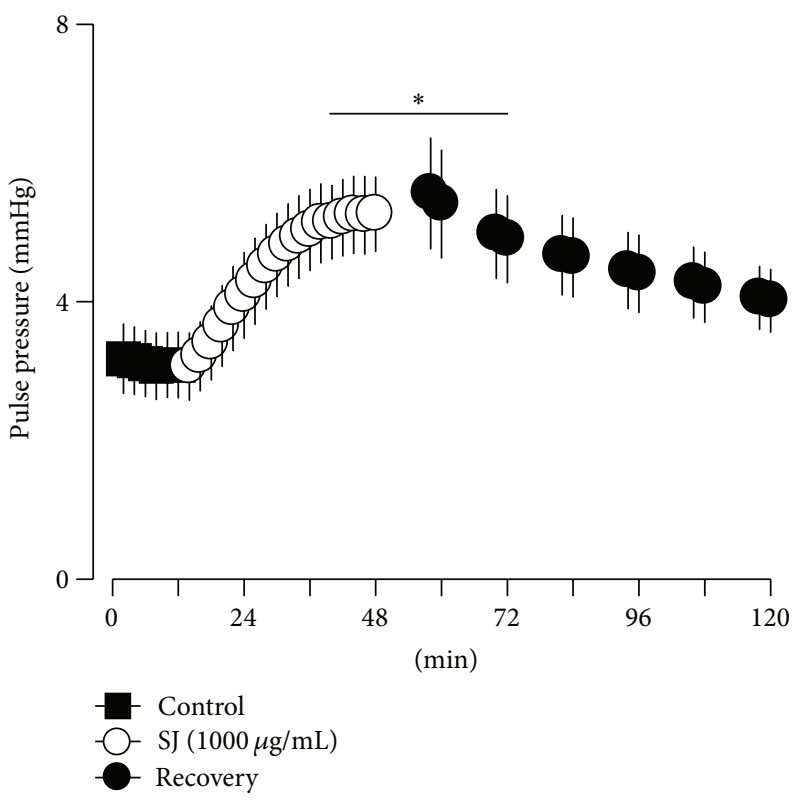

(b)

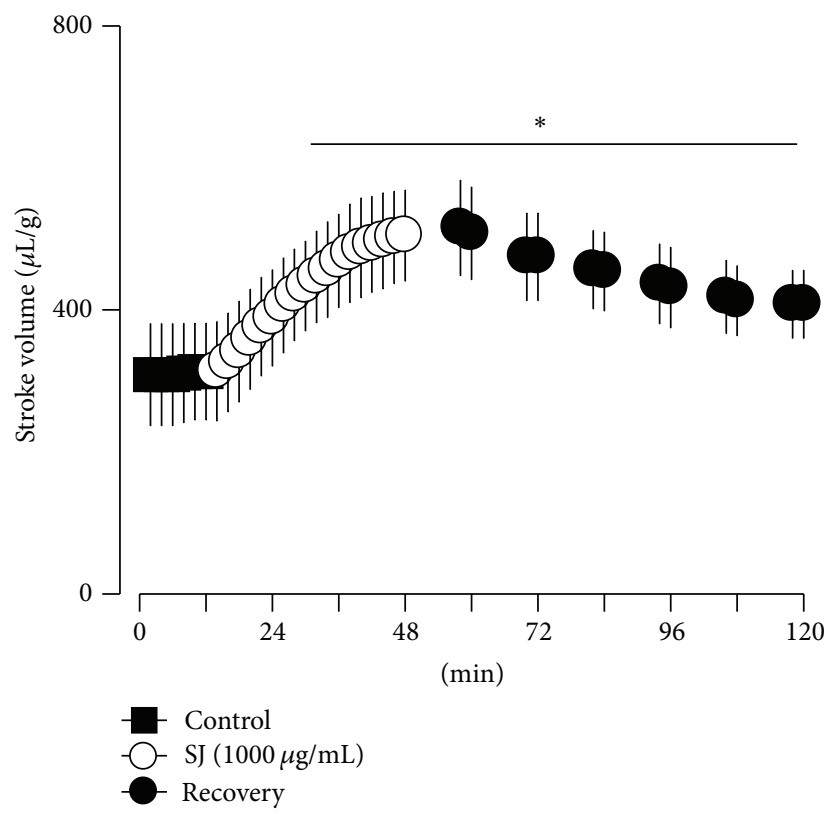

(c)

FIGURE 5: Recovery from the effects of Sibjotang (SJ) after replacing the buffer without the agent. (a) Recovery from the effects of SJ $(1,000 \mu \mathrm{g} / \mathrm{mL})$ on ANP secretion. (b) Recovery from the effects of SJ on pulse pressure. (c) Recovery from the effects of SJ on stroke volume. Values are mean \pm SE. Number of experiments, $n=4 .{ }^{*} P<0.05,{ }^{* *} P<0.01$ versus mean values of two fractions before SJ.

induced increase in ANP secretion and positive inotropic effects. GO $(100 \mathrm{nM})$, a selective inhibitor of conventional $\mathrm{PKC}_{\alpha}$, inhibited SJ-induced changes in ANP secretion and atrial dynamics (Figure 6). However, Rott $(1,000 \mathrm{nM})$, an inhibitor of novel $\mathrm{PKC}_{\delta}$, had no significant effect on the SJ- $(100 \mu \mathrm{g} / \mathrm{mL})$ induced increase in ANP secretion and arial dynamics (Figure 6). LY, GO, and Rott alone slightly but significantly decreased ANP secretion, and GO and Rott decreased atrial dynamics (Figure 6). These findings indicated that SJ increased ANP secretion and atrial dynamics via activation of conventional PKC signaling pathway.

3.4. Effects of Extract of Components Herbs and Ingredients of SJ. To identify the roles of component herbs of the SJ, effects of four component herb extracts were separately tested. Extract of Euphorbia kansui, in the same concentration contained in SJ $(1,000 \mu \mathrm{g} / \mathrm{mL})$, increased ANP secretion and atrial dynamics (Figure 7). Similarly, Daphne genkwa 


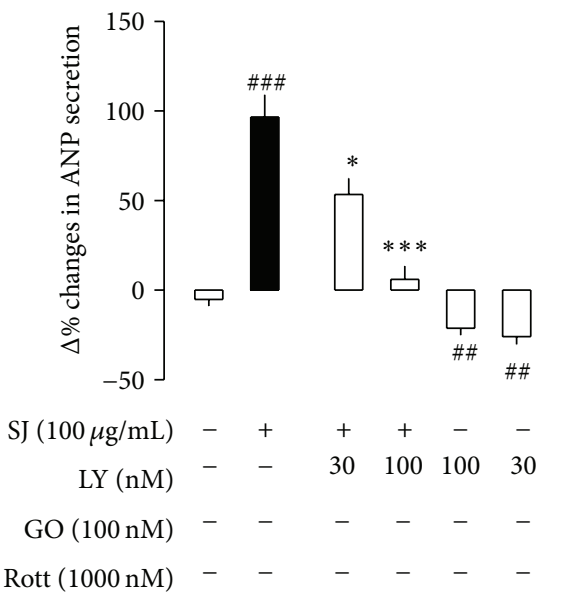

(a)

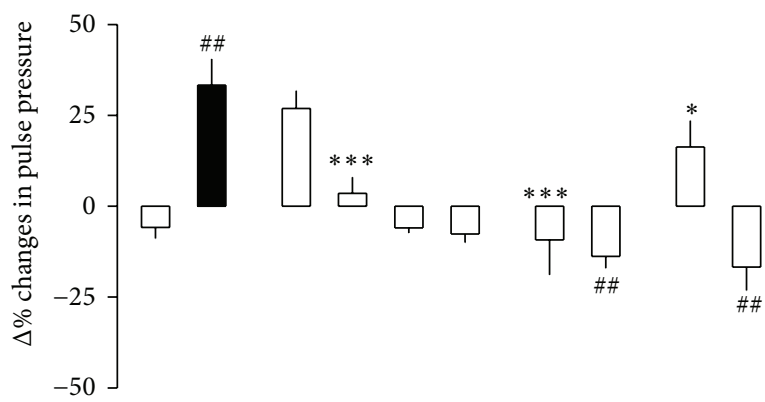

$\begin{array}{rccccccccccc}\mathrm{SJ}(100 \mu \mathrm{g} / \mathrm{mL}) & - & + & + & + & - & - & + & - & + & - \\ \mathrm{LY}(\mathrm{nM}) & - & - & 30 & 100 & 100 & 30 & - & - & - & - \\ \mathrm{GO}(100 \mathrm{nM}) & - & - & - & - & - & - & + & + & - & - \\ \operatorname{Rott}(1000 \mathrm{nM}) & - & - & - & - & - & - & - & - & + & +\end{array}$

(b)

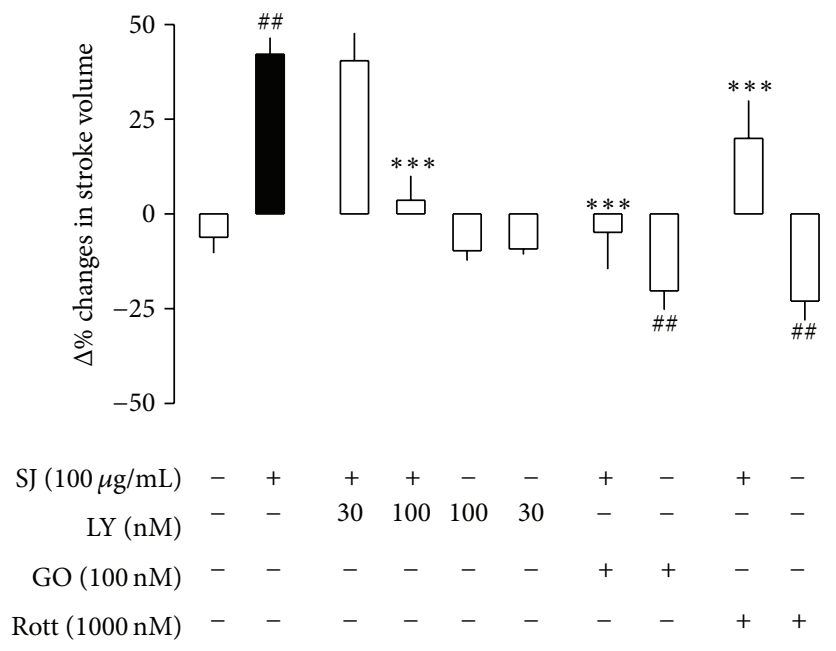

(c)

FIGURE 6: Effects of subtype-selective inhibitors of protein kinase C on the Sibjotang- (SJ-) induced increase in ANP secretion, pulse pressure, and stroke volume in atria. (a) Effects of inhibitors of protein kinase C on the SJ- (100 $\mu \mathrm{g} / \mathrm{mL}$ ) induced increase in ANP secretion. (b) Effects of inhibitors of protein kinase $\mathrm{C}$ on the SJ-induced increase in pulse pressure. (c) Effects of inhibitors of protein kinase C on the SJ-induced increase in stroke volume. Values are mean \pm SE. Number of experiments: control, $n=8 ;$ SJ $(100 \mu \mathrm{g} / \mathrm{mL}), n=9 ; \mathrm{LY} 333531(\mathrm{LY}) 30 \mathrm{nM}+\mathrm{SJ}$, $n=12$; LY $30 \mathrm{nM}+$ vehicle, $n=6$; LY $100 \mathrm{nM}+\mathrm{SJ}, n=8$; LY $100 \mathrm{nM}+$ vehicle, $n=5$; GO6976 (GO) + SJ, $n=9$; GO + vehicle, $n=5$; Rottlerin (Rott) + SJ, $n=8$; and Rott + vehicle, $n=6 .{ }^{*} P<0.05,{ }^{* * *} P<0.001$ versus SJ; ${ }^{\# \#} P<0.01,{ }^{\# \# \#} P<0.001$ versus control.

enhanced ANP secretion and atrial dynamics (Figure 7). However, extracts of Euphorbia pekinensis and Ziziphus jujube rather decreased ANP secretion (Figure 7(a)). Both extracts showed a negative inotropic effect (Figures $7(\mathrm{~b})$ and $7(c)$ ). To further identify the effects of chemical ingredients of the herbal components of SJ, experiments were performed. Because SJ contains apigenin, rosmarinic acid, and salvianolic acid B (Figure 2), experiments were performed to identify the effects of the ingredients on the ANP secretion and atrial dynamics. Apigenin $(10 \mathrm{nM})$, rosmarinic acid $(1.0 \mu \mathrm{M})$, and salvianolic acid B $(1.0 \mu \mathrm{M})$ decreased ANP secretion by $-23.34 \pm 6.80 \%,-45.24 \pm 8.20 \%$, and $-47.40 \pm 5.28 \%$ (all $P<0.001$ versus corresponding control group), respectively. Rosmarinic acid and salvianolic acid $\mathrm{B}$ but not apigenin decreased atrial pulse pressure by $-7.93 \pm 3.42 \%$ and $-8.22 \pm$ $1.48 \%$ (both $P<0.001$ versus control group), respectively.

\section{Discussion}

The present study shows that a traditional herbal medicine SJ increases ANP secretion and atrial dynamics in perfused beating rabbit atria. The effects of SJ were concentrationdependent and persistent. SJ resulted in an increase in ANP secretion and positive inotropic effects via activation of conventional PKC subtypes. Conventional $\mathrm{PKC}_{\alpha}$ and $\mathrm{PKC}_{\beta}$ inhibitors, GO and LY, respectively, but not novel $\mathrm{PKC}_{\delta}$ inhibitor, Rott, attenuated SJ-induced increase in ANP secretion and atrial dynamics. In the regulation of ANP secretion from the heart, the involvement of PKC has been known. Previously, it was shown that phorbol ester, known to be an activator of PKC, accentuated the stretch-induced increase in ANP secretion from the atria $[12,19]$. The present finding is consistent with the reports, furtherly suggesting the 


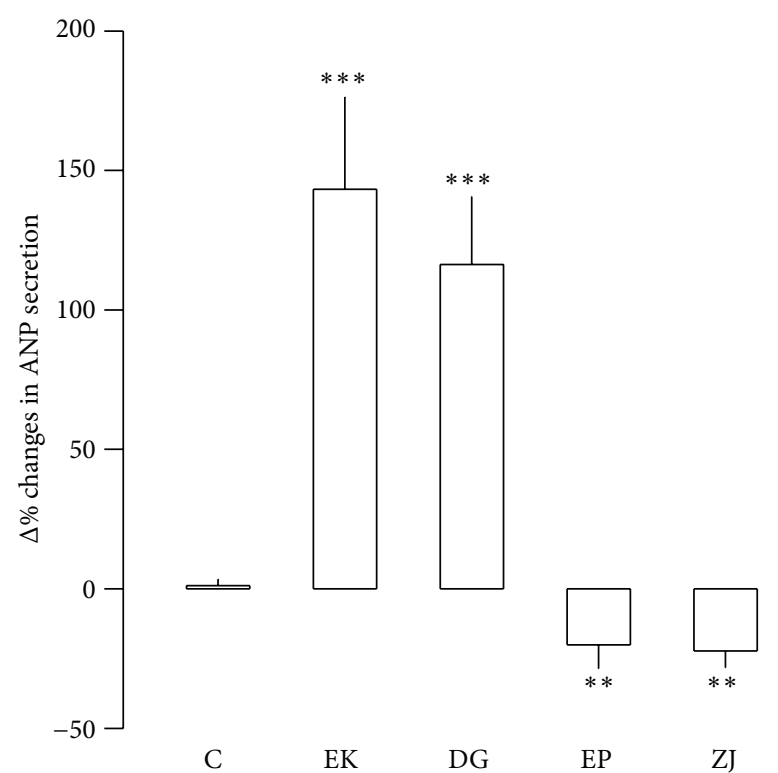

(a)

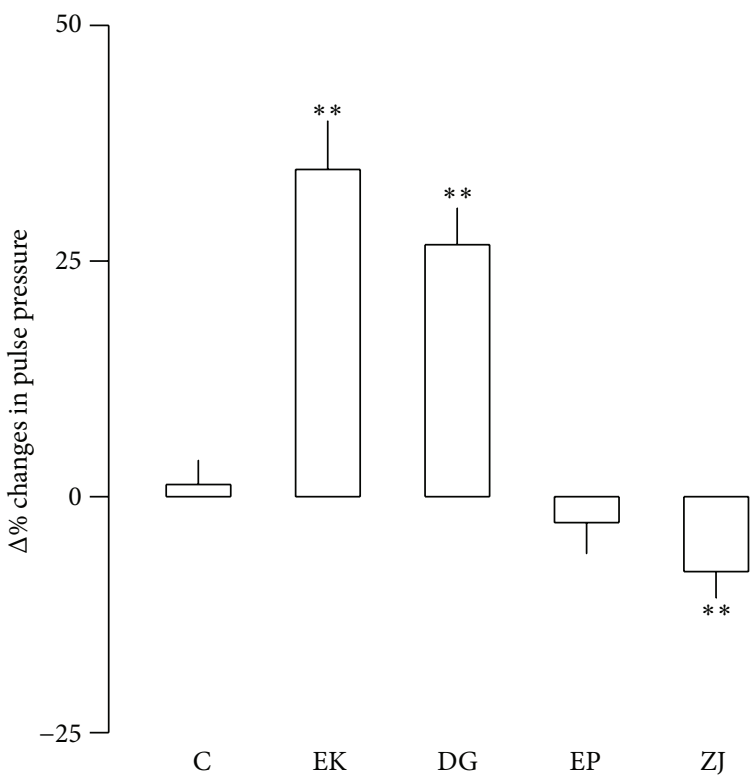

(b)

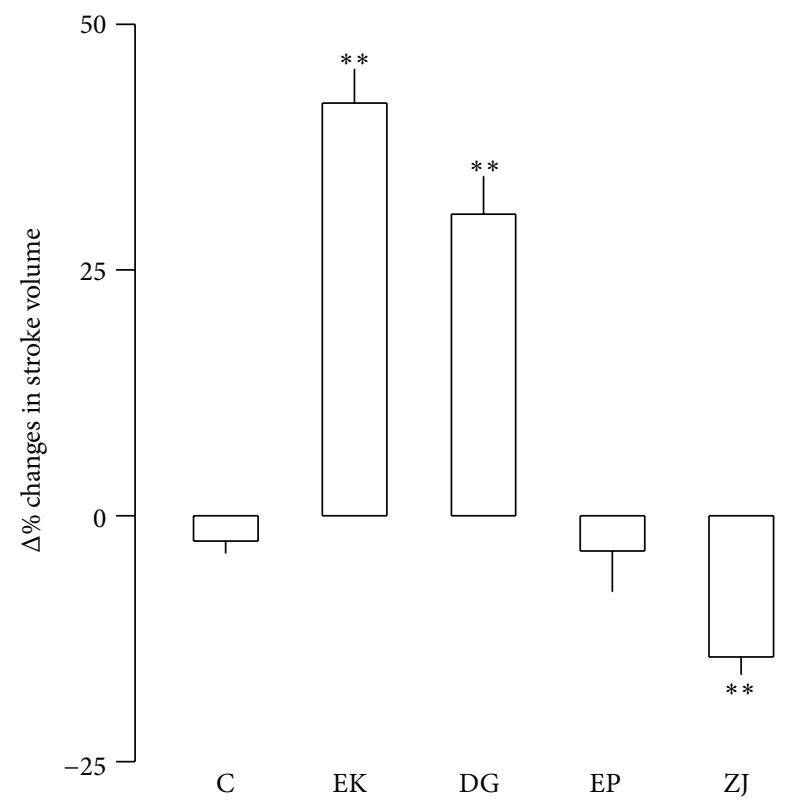

(c)

FIGURE 7: Effects of extract of component herbs of SJ, Euphorbia kansui (EK), Euphorbia pekinensis (EP), Daphne genkwa (DG), and Ziziphus jujube (ZJ) on ANP secretion, pulse pressure, and stroke volume in perfused beating rabbit atria. (a) Effects of extract of component herbs on ANP secretion. (b) Effects of extract of component herbs on pulse pressure. (c) Effects of extract of component herb on stroke volume. Values are mean \pm SE. Number of experiments: control (C), $n=6 ; n=7$ for each of other groups. ${ }^{* *} P<0.01,{ }^{* * *} P<0.001$ versus control.

involvement of $\mathrm{PKC}_{\alpha}$ and $\mathrm{PKC}_{\beta}$ signaling pathways in SJinduced ANP secretion and atrial dynamics.

Extracts of two components of SJ, Euphorbia kansui and Daphne genkwa, increased ANP secretion and atrial dynamics similarly to SJ, while those of two other components slightly but significantly suppressed the secretory function. Although the roles of the latter two components are yet unknown, these findings suggest that Euphorbia kansui and Daphne genkwa are the main components in eliciting accentuation of cardiac hormone secretion and positive inotropic effect. The other two component herbs may conduct their role indirectly through modifying the effects of Euphorbia kansui and Daphne genkwa. Apigenin, rosmarinic acid, and salvianolic acid, chemical ingredients of SJ, decreased the atrial secretory and contractile function. Therefore, this latter finding suggests that apigenin, rosmarinic acid, and salvianolic acid B may not be directly involved in the atrial effects of SJ.

SJ-induced increase in ANP secretion may not be related to myocardial injury. The levels of $\mathrm{LDH}$ activity in perfusate 
were not significantly different between the values of before and after SJ $(100 \mu \mathrm{g} / \mathrm{mL})$. A slight but transient increase in LDH levels during the infusion of higher concentration of SJ $(1,000 \mu \mathrm{g} / \mathrm{mL})$ which has disappeared after cessation of the drug may be related to the increased washout of the enzyme in the extracellular space of the atrium because during this period atrial dynamics increased (Figure 4). Previously, it was shown that increase in atrial dynamics enhanced the extracellular fluid translocation in beating rabbit atria $[8,20]$.

The present study suggests that SJ could ameliorate impairment of the regulation of body fluid and blood pressure homeostasis via activation of the ANP system. Plasma levels of ANP are regulated by both the secretion from the atria and metabolism via degradation with neutral endopeptidase and clearance through nonguanylyl cyclase coupled natriuretic peptide receptor-C $[21,22]$. Activation of ANP secretion induces an increase in the levels of plasma ANP and then urinary excretion of fluid and salt. The ANP system is also involved in the regulation of blood pressure via guanylyl cyclase-coupled natriuretic peptide receptor-A/B-cGMP signaling [1].

In conclusion, Sibjotang, traditional herbal medicine, induces an increase in ANP secretion and positive inotropic effects via activation of PKC signaling. The present study provides experimental evidence for the rationale in the use of SJ in the treatment of impairment of body fluid and blood pressure homeostasis.

\section{Conflict of Interests}

The authors declare that there is no conflict of interests regarding the publication of this paper.

\section{Acknowledgment}

This work was supported by the National Research Foundation of Korea (NRF) Grant funded by the Korean Government (MSIP) (2008-0062484) (NRF2014R1A2A2A01005101).

\section{References}

[1] L. R. Potter, S. Abbey-Hosch, and D. M. Dickey, "Natriuretic peptides, their receptors, and cyclic guanosine monophosphatedependent signaling functions," Endocrine Reviews, vol. 27, no. 1, pp. 47-72, 2006.

[2] A. K. Kiemer and A. M. Vollmar, "The atrial natriuretic peptide regulates the production of inflammatory mediators in macrophages," Annals of the Rheumatic Diseases, vol. 60, supplement 3, pp. iii68-iii70, 2001.

[3] K. Sangawa, K. Nakanishi, K. Ishino, M. Inoue, M. Kawada, and S. Sano, "Atrial natriuretic peptide protects against ischemiareperfusion injury in the isolated rat heart," Annals of Thoracic Surgery, vol. 77, no. 1, pp. 233-237, 2004.

[4] D. L. Vesely, "Cardiac and renal hormones: anticancer effects in vitro and in vivo," Journal of Investigative Medicine, vol. 57, no. 1, pp. 22-28, 2009.

[5] P. De Vito, S. Incerpi, J. Z. Pedersen, and P. Luly, "Atrial natriuretic peptide and oxidative stress," Peptides, vol. 31, no. 7, pp. 1412-1419, 2010.
[6] C. Sengenès, A. Bouloumié, H. Hauner et al., "Involvement of a cGMP-dependent pathway in the natriuretic peptidemediated hormone-sensitive lipase phosphorylation in human adipocytes," The Journal of Biological Chemistry, vol. 278, no. 49, pp. 48617-48626, 2003.

[7] C. Moro and M. Lafontan, "Natriuretic peptides and cGMP signaling control of energy homeostasis," American Journal of Physiology: Heart and Circulatory Physiology, vol. 304, no. 3, pp. H358-H368, 2013.

[8] K. W. Cho, S. H. Kim, C. H. Kim, and K. H. Seul, "Mechanical basis of ANP secretion in beating atria: atrial stroke volume and ECF translocation," American Journal of Physiology, vol. 268, no. 5, pp. R1129-R1136, 1995.

[9] D. Y. Xu, J. F. Wen, H. X. Quan et al., "K ${ }^{+}$ACh channel activation with carbachol increases atrial ANP release," Life Sciences, vol. 82, no. 21-22, pp. 1083-1091, 2008.

[10] H. Y. Kim, K. W. Cho, D. Y. Xu, D. G. Kang, and H. S. Lee, "Endogenous ACh tonically stimulates ANP secretion in rat atria," American Journal of Physiology-Heart and Circulatory Physiology, vol. 305, no. 7, pp. H1050-H1056, 2013.

[11] J. F. Wen, X. Cui, J. Y. Jin et al., "High and low gain switches for regulation of cAMP efflux concentration: distinct roles for particulate GC- and soluble GC-cGMP-PDE3 signaling in rabbit atria," Circulation Research, vol. 94, no. 7, pp. 936-943, 2004.

[12] H. Ruskoaho, O. Vuolteenaho, and J. Leppäluoto, "Phorbol esters enhance stretch-induced atrial natriuretic peptide secretion," Endocrinology, vol. 127, no. 5, pp. 2445-2455, 1990.

[13] H. Z. Cui, J. F. Wen, H. R. Choi et al., "Ursolic acid increases the secretion of atrial natriuretic peptide in isolated perfused beating rabbit atria," European Journal of Pharmacology, vol. 653, no. 1-3, pp. 63-69, 2011.

[14] A. Watzke, S. J. O’Malley, R. G. Bergman, and J. A. Ellman, "Reassignment of the configuration of salvianolic acid B and establishment of its identity with lithospermic acid B," Journal of Natural Products, vol. 69, no. 8, pp. 1231-1233, 2006.

[15] Y. Sun, H. Zhu, J. Wang, Z. Liu, and J. Bi, "Isolation and purification of salvianolic acid A and salvianolic acid B from Salvia miltiorrhiza by high-speed counter-current chromatography and comparison of their antioxidant activity," Journal of Chromatography B: Analytical Technologies in the Biomedical and Life Sciences, vol. 877, no. 8-9, pp. 733-737, 2009.

[16] Y. Lu and L. Y. Foo, "Rosmarinic acid derivatives from Salvia officinalis," Phytochemistry, vol. 51, no. 1, pp. 91-94, 1999.

[17] F. Moussaoui, A. Zellagui, N. Segueni, A. Touil, and S. Rhouati, "Flavonoid constituents from Algerian Launaea resedifolia (O.K.) and their antimicrobial activity," Records of Natural Products, vol. 4, no. 1, pp. 91-95, 2010.

[18] S. Ayers, D. L. Zink, K. Mohn et al., "Flavones from Struthiola argentea with anthelmintic activity in vitro," Phytochemistry, vol. 69, no. 2, pp. 541-545, 2008.

[19] M. Pitkänen, P. Mäntymaa, and H. Ruskoaho, "Staurosporine, a protein kinase $\mathrm{C}$ inhibitor, inhibits atrial natriuretic peptide secretion induced by sarafotoxin, endothelin and phorbol ester," European Journal of Pharmacology, vol. 195, no. 3, pp. 307-315, 1991.

[20] K. W. Cho, S. J. Lee, J. F. Wen, S. H. Kim, K. H. Seul, and H. S. Lee, "Mechanical control of extracellular space in rabbit atria: an intimate modulator of the translocation of extracellular fluid and released atrial natriuretic peptide," Experimental Physiology, vol. 87, no. 2, pp. 185-194, 2002.

[21] K. Graf, P. Koehne, M. Grafe, M. Zhang, W. Auch-Schwelk, and E. Fleck, "Regulation and differential expression of neutral 
endopeptidase 24.11 in human endothelial cells," Hypertension, vol. 26, no. 2, pp. 230-235, 1995.

[22] F. L. Martin, T. L. Stevens, A. Cataliotti et al., "Natriuretic and antialdosterone actions of chronic oral NEP inhibition during progressive congestive heart failure," Kidney International, vol. 67, no. 5, pp. 1723-1730, 2005. 


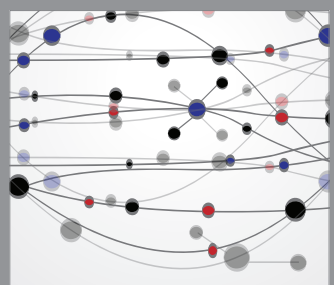

The Scientific World Journal
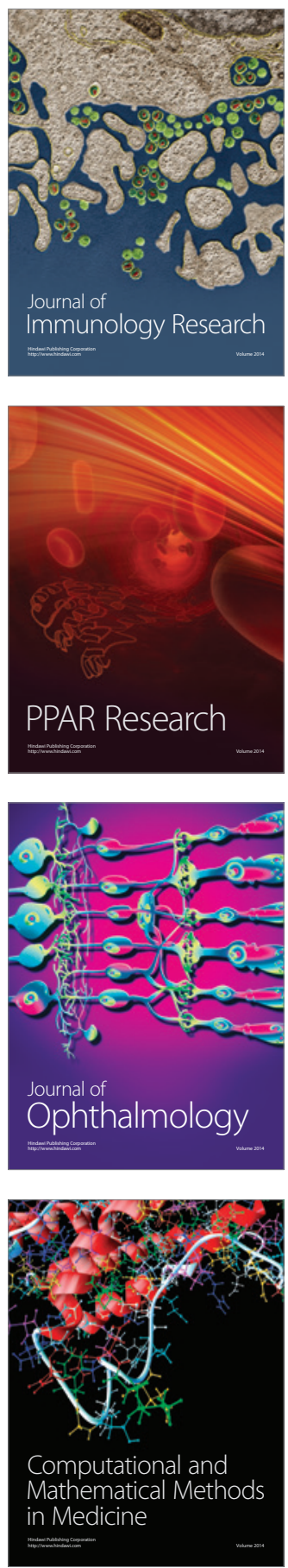

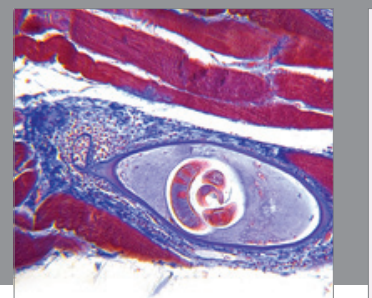

Gastroenterology

Research and Practice
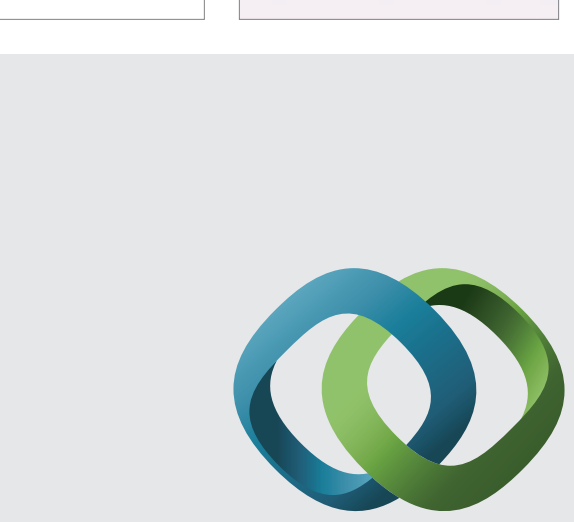

\section{Hindawi}

Submit your manuscripts at

http://www.hindawi.com
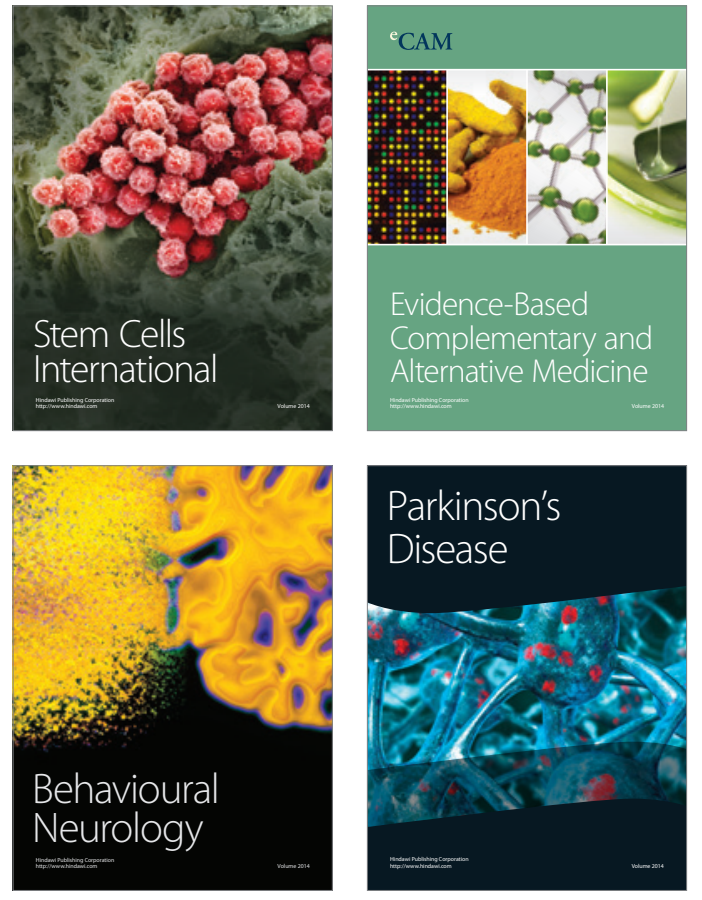
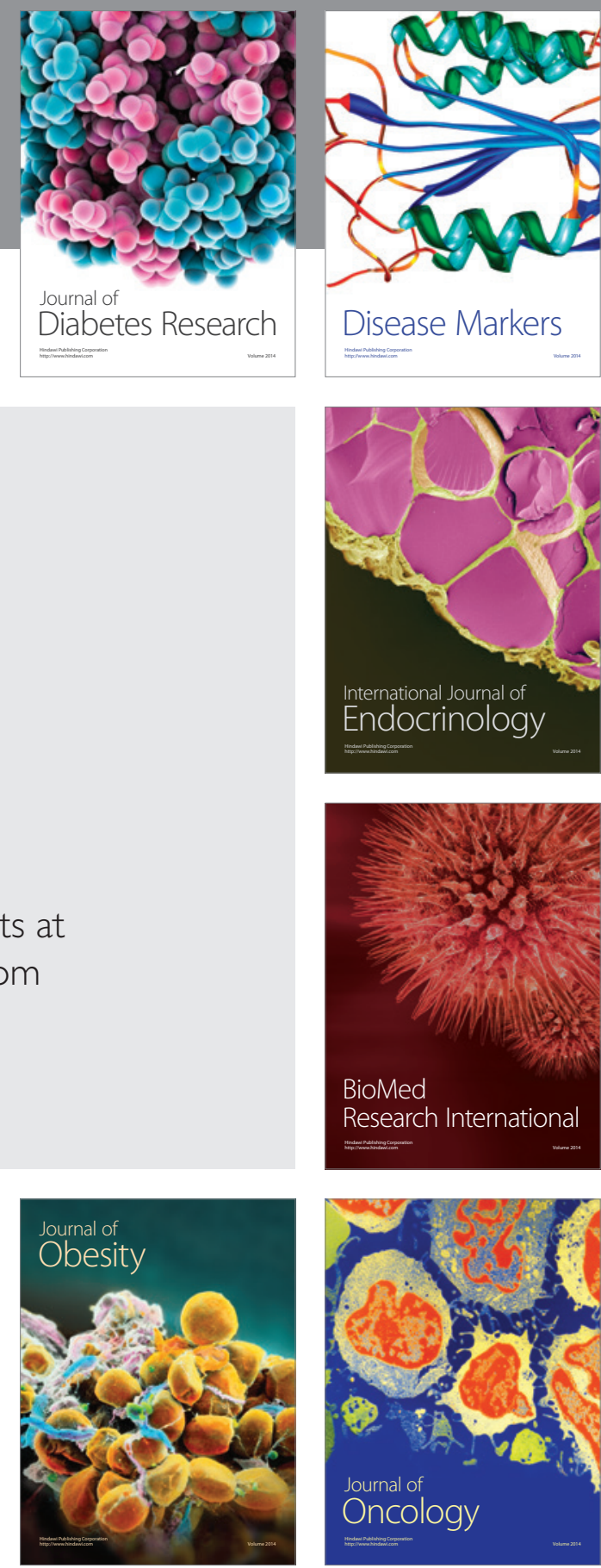

Disease Markers
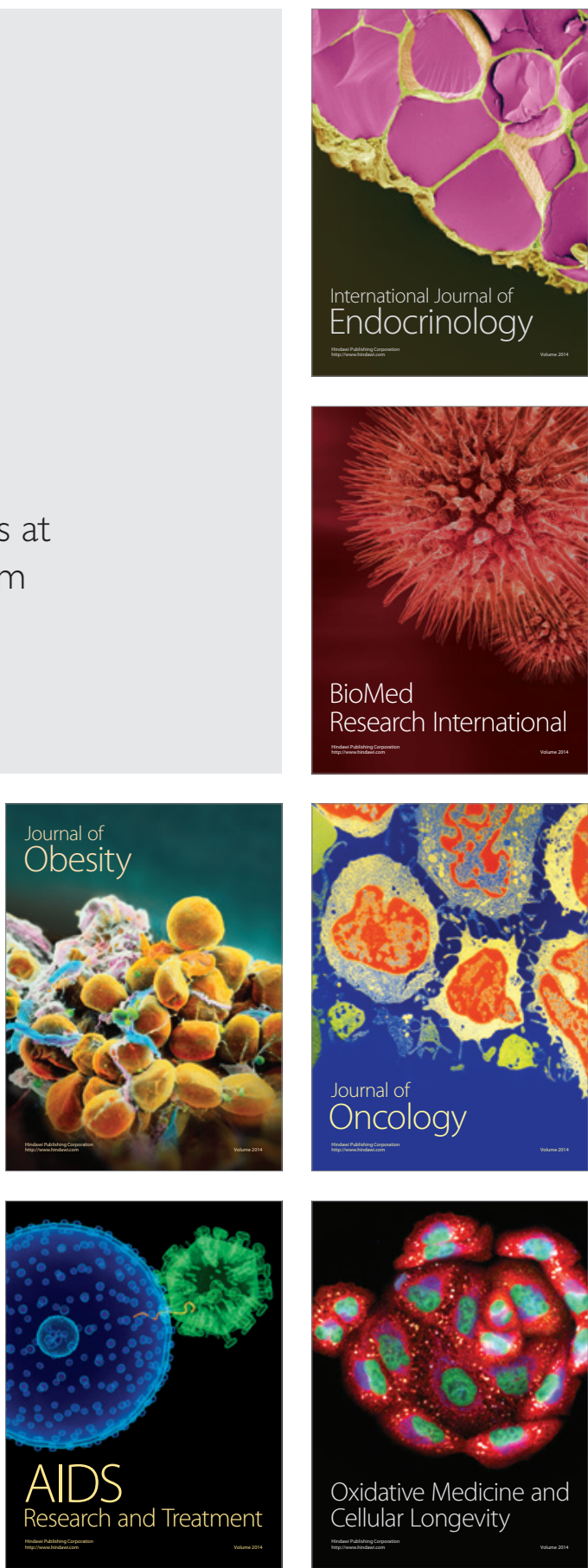